\title{
DIGITÁLIS ZÖLDség A MISKOLCI EGYETEMEN, AVAGY AZ A4-ES PIXELEK KÖRNYEZETKÁROSÍTÓ LÁBNYOMA
}

\author{
Varga Attila Károly \\ egyetemi docens, Miskolci Egyetem, Gépészmérnöki és Informatikai Kar, \\ Automatizálási és Infokommunikációs Intézet \\ 3515 Miskolc, Miskolc-Egyetemváros, e-mail:vvarga.attila@uni-miskolc.hu
}

\author{
Sitku Ádám György \\ programtervezö informatikus alapszakos hallgató, Miskolci Egyetem, Gépészmérnöki és Informatikai Kar, \\ Automatizálási és Infokommunikációs Intézet \\ 3515 Miskolc, Miskolc-Egyetemváros, e-mail: sitku1@iit.uni-miskolc.hu
}

\begin{abstract}
Absztrakt
Az Europapier adatai szerint a világon évente közel 370 millió tonna papirt használnak fel, az I-COM irodaszereket forgalmazó vállalat papírpiaci elemzése szerint egy magyar ember $91 \mathrm{~kg}$ papírt használ

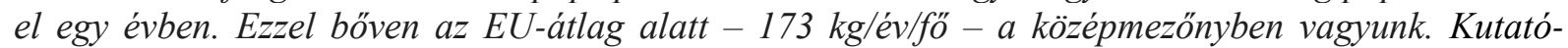
munkánkkal arra kerestük a választ, hogy a Miskolci Egyetemet milyen mértékü éves irodai papirfelhasználás jellemzi. A napi adminisztrativ teendők és a projektek által megkivánt papír alapú dokumentálás és archiválás generálta irodai papirfelhasználásból kiindulva, az A4-es papirfelhasználást vizsgáltuk, tekintettel arra, hogy zöld megoldások és környezettudatos munkavégzés kapcsán végzett nemzetközi kutatások is rámutattak, hogy a munkafolyamatokban leggyakrabban használt A4-es irodai papir tudatosan, jól átgondolt felhasználása esetén jelentös költségmegtakaritás érhetö el, hatékonyabbá téve a munkavégzést, csökkentve a környezeti hatásokat.
\end{abstract}

Kulcsszavak: papirhulladék, digitalizáció, információs rendszerek, környezetbarát, újrapapír

\begin{abstract}
Europapier estimates that around 370 million tonnes of paper are used worldwide each year. According to the paper market analysis of the I-COM office supply company one Hungarian man consumes $91 \mathrm{~kg}$ of paper a year. This is well below the EU average of $173 \mathrm{~kg} /$ year / capita. During our research, we have been looking for an answer to the degree of annual office paper use at the University of Miskolc. Starting from the paper consumption generated by the paper based documentation and archiving required by the daily administrative tasks and projects, we only examined A4 paper consumption, given that international studies on green solutions and environment-friendly jobs have shown that conscious, well-thought-out use of A4 office paper in workflows saves costs, makes work more efficient and greener as well as reducing the environmental impact of their operations.
\end{abstract}

Keywords: waste paper, digitization, information systems, environmentally friendly, recycled paper

\section{Bevezetés}

A papír mindennapi életünk szerves részévé vált, ugyanakkor a kényelmes és a könnyü használata miatt sokszor meggondolatlanul, megfontolás nélkül pazaroljuk. Az nagymértékü papírfogyasztás sokszor a papírfelhasználással kapcsolatos tudatosság ismereteinek hiányának tudható be. A Miskolci 
Egyetem a legtöbb hazai és nemzetközi felsőoktatási intézményhez hasonlóan oktatási és kutatási profiljából adódóan szerepet játszik a környezeti szempontból fenntartható munkagyakorlatok kialakításában és végrehajtásában, valamint a fenntarthatóságnak az oktatásba és kutatásba való beépítésében.

Mindennapi tevékenységeink során mérlegelnünk kell a környezeti, társadalmi és gazdasági szempontokat és hatásokat, valamint a természeti erőforrások felelősségteljes kezelésének és felhasználásának szükségességét. Az egyetemi tevékenységek, akárcsak más nagy szervezetek tevékenységei, potenciálisan jelentős környezeti, társadalmi és gazdasági hatásokat eredményezhetnek. A Miskolci Egyetemen folytatott oktatási és $\mathrm{K}+\mathrm{F}+\mathrm{I}$ tevékenységek versenyképességének fenntartása és erősitése, mint stratégia célkitüzés kiemelt prioritással kezelendő. Az egyetemektől a müködésüket illetően más szervezetektől eltérően - alapvetően elvárt a fenntartható jövő felé való elmozdulást. A Miskolci Egyetem a világ számos egyeteméhez hasonlóan hosszú távú fenntarthatóságot kíván megvalósítani az oktatásban, a kutatásban és a mindennapi müködésében.

Az intézményen belül felhasznált irodai A4-es papír mennyiségének, valamint a fogyasztás okának és kontextusának ismerete a szervezeten belül fontos lépés a Miskolci Egyetem működésének papírhasználattal kapcsolatos környezeti hatásainak csökkentésében. Erre való tekintettel különösen fontosnak tartottuk a globális digitalizáció korszakában megvizsgálni a Miskolci Egyetem papírfelhasználási szokásait az A4-es irodai papír vonatkozásában.

\section{PAPÍR rövid története}

A papírnak kezdettől fogva a gondolatok rögzítésére szolgáló írás hordozása volt a fő feladata. Feltalálása és készítésének az egész világon való elterjedése előtt ilyen célra agyag-, kő-, fém- és viasztáblákat, növények szárából készült lapokat, fakérget és állatböröket használt az ember.

Az első papírgyártási folyamatot Kínában dokumentálták a keleti han időszakban (Kr. után 25220), amelyet egy Cai Lun nevü bírósági tisztviselőnek tulajdonítottak. A legújabb régészeti leletek azt bizonyítják, hogy növényszerủ rostokból készült papírt már Kr.e. 140-87 között használtak. A 8. század folyamán a kínai papírgyártás elterjedt az iszlám világban, majd a 11. századra a papírgyártás Európába is eljutott. A 13. századra a papírgyártás finomításra került spanyolországi vízkerekeket használó papírgyárakkal. A 19. században a papírgyártás folyamatában jelentős fejlődés figyelhető meg a faalapú papírok gyártásával.

A papír hazai alkalmazása az Anjouk korában kezdődött el. A papír egészen a 14. századig nem volt népszerü, mert úgy gondolták, hogy nem elég tartós. Később azonban, amikor az addig használatos pergamen ára jócskán megemelkedett, a papír egyre elterjedtebbé vált. Az igazi áttörést a 19. században felfedezett gőzhajtású papírmalom hozta, amelyben már fából állították elő a papírgyártáshoz szükséges rostokat. [1,2]

\section{A papírgyártás környezeti hatásai}

A papír legfontosabb alkotója a cellulóz, emiatt a papírgyártás elsődleges célja, hogy a növényi rostokban lévő cellulóz mellől az egyéb kísérő anyagokat eltávolítsák. A papírgyártáshoz szükséges rost leggyakrabban ültetvényből vagy természetes erdőkből betakarított fából, valamint újrahasznosított papírból és kartonból származik. [3] Az ültetvényből vagy a természetes erdőkből származó rost származhat fenntarthatóan kezelt erdőkből, fenntarthatatlanul kezelt erdőkből vagy illegális erdőgazdálkodásból. A természetes erdőkből származó rostok esetén olyan környezeti problémákkal szembesülünk, mint erdőirtás, erdőpusztulás, biodiverzitás csökkenése és globális felmelegedés. A rost cellulózként történő feldolgozása szintén számos környezetkárosító hatással bír: víz- és az energiafogyasztás, 
üvegházhatású gázok, kén-dioxid, nitrogén-oxidok és illékony szerves vegyületek kibocsátása, dioxinok és szilárd hulladékok ártalmatlanítása. [3,4] A papíripar majdnem kétezer fajta vegyi anyagot használ fel. Az egyre növekvő papírfogyasztás a nyersanyag (fa), az energia és a víz egyre nagyobb mértékü felhasználásával jár. Egy tonna papírt három tonna fa felhasználásával állíthatunk elö, miközben annyi energiát használunk el, amennyit egy átlagos háztartás egy év alatt. Jelenleg a világ éves fakitermelésének mintegy 20 \%-át használják fel papír elöállításához. A legnagyobb környezeti problémát azonban maga a papírgyártás folyamata okozza. A gyártók technológiai újításaikkal folyamatosan igyekeznek mérsékelni az általuk okozott környezeti károkat. Tíz év alatt felére csökkent az egy kilogramm papír előállításához szükséges víz és energiamennyiség. Mivel azonban a papírfelhasználás mértéke az újabb és újabb igények miatt folyamatosan nő, hiába lett kisebb az egységnyi papír előállítására eső környezetterhelés, a szennyezés összességében alig-alig csökkent. [1] A globális környezetvédelmi problémák - például a levegő és a víz szennyeződése, az éghajlatváltozás, az elárasztott hulladéklerakók és az erdőirtás - fokozódása miatt világszerte erőteljes kormányzati szabályozásokra volt szükség.

A cellulóz- és papírgyártás során kibocsátott szennyvíz szilárd anyagokat, tápanyagokat és oldott szerves anyagokat (például lignint) tartalmaz. Ezen túlmenően alkoholokat, kelátképző anyagokat és szervetlen anyagokat (például klorátokat és fémvegyületeket) is tartalmaz. A nitrogén és a foszfor, okozhatják vagy fokozhatják az édesvízkészletek növényi tápanyagdúsulását (eutrofizációját), amelyet követ az algásodás, hínárosodás, azaz a víz trofitásfokának növekedése.

Fontos megjegyezni, hogy a cellulóz- és papíriparban jelenleg a fenntarthatóság irányába mutató tendencia mutatkozik, mivel a legújabb technológiák alkalmazása csökkenti az erdőirtást, a vízfelhasználást, az üvegházhatású gázok kibocsátását, a fosszilis tüzelőanyagok fogyasztását és a helyi vízellátásra és a légszennyezésre gyakorolt hatásait [5,7-10].

\section{Papírfelhasználási tendenciák, fogyasztói preferenciák}

A papírfelhasználás az egész világon 400\%-kal nőtt az elmúlt 40 évben, a betakarított fák $35 \%$-át papírgyártáshoz használták fel. Ma már a világ éves papírfelhasználása meghaladja a 400 millió tonnát. Az ültetvényes erdők, ahonnan a pépesített fa nagy részét nyerik, általában monokultúra, és ez aggályokat vet fel a gyakorlat ökológiai hatásaival kapcsolatban.

2006-ban több mint 6,5 millió fát vágtak ki, hogy 16 milliárd papírpoharat készítsenek az amerikai kávéfogyasztók számára, $15.000 .000 \mathrm{~m}^{3}$ vizet felhasználva, és 115 ezer tonna hulladékot eredményezve. [11,12] A papírhulladék, más hulladékokhoz hasonlóan, további veszélyt jelent a mérgező tinták, festékek és polimerek miatt, amelyeknek potenciálisan rákkeltő hatása lehet égetéskor vagy a talajvízbe szivárogva hagyományos hulladékkezelési módszerek alkalmazása esetén. A papír újrahasznosítása enyhíti ezt a hatást, de a papírtermékek gyártása, szállítása, eltemetése vagy újrafeldolgozása során felhasznált energia környezeti és gazdasági hatásait nem.

Az utóbbi időkben egyre inkább általánosabb az a vélekedés, hogy a hulladéklerakók negatív hatásainak csökkentése érdekében az újrahasznosítás irányába kell elmozdulni, mivel a papírhulladék lerakásának és elzárásának jelentős környezetkárosító hatása van. Fontos megemlíteni, hogy a legtöbb újrahasznosított papír ára magasabb, mint az újonnan készített papíré, mely jelentősen befolyásolja a fogyasztó vásárlási szokásait, döntéseit. [5,13] A fogyasztói preferenciával kapcsolatos statisztikák szerint [14]:

- A fiatalok 80,5\%-a nem tudna élni papír nélkül.

- A fiatalok (föleg a nők) 72\%-a használ papírt írott kommunikációra napi rendszerességgel.

- A megkérdezettek 75.9\%-a úgy gondolja, hogy a print hirdetések éppoly hatásosak, vagy még hatásosabbak, mint az internetes reklámok. 
- A válaszadók fele a printet tartja a leghatékonyabb marketing médiumnak a ráfordított költség szempontjából.

- Az emberek 60\%-a egy héten belül rendel valamilyen árut az interneten egy nyomtatott katalógus elolvasása után.

- A digitális hírvásárlók majdnem 90\%-a szeretne a továbbiakban is hozzáférni a nyomtatott lapokhoz, és azokat akár saját otthonában, akár a boltban böngészni.

- Mindazoknak, akik digitális médiumon olvasnak híreket, csupán 11\%-a nem használ már papírt egyáltalán.

- A fogyasztók $60 \%$-a idegenkedik az olyan társaságoktól, akik nem ajánlják fel a papír alapú számlázás lehetőségét.

- A fogyasztók szerint a nyomtatott számlák könnyebben olvashatók, 38\%-a rendszeresen kinyomtatja otthon a számláit.

A közigazgatás és az üzleti élet információinak legnagyobb részét még ma is papíron tárolják. A felesleges adminisztráció, a reklámanyagok, szórólapok is tovább növelik ezt a mennyiséget, holott a számítógép és internet korában az információk tárolása és megjelenítése elektronikus úton is megtörténhet.

\section{Papír vs. digitális technológia}

Statisztikák arra mutattak rá, hogy egy átlagos irodai alkalmazott naponta hat felesleges oldalt nyomtat, amiből kilencven százalék körüli az interneten elérhető és tárolt tartalmak aránya. Ennek környezeti szempontból különösen azért van nagy jelentősége, mert:

- egy idős fa egy év alatt közel 200 kg-nyi oxigént termel, többet, mint amennyit egy ember egy év alatt felhasznál,

- egy átlagos európai háztartás évente hat fa életét dobja a kukába,

- a világ éves fakitermelésének mintegy $20 \%$-át használják fel papír elóállításához,

- a papíripar majdnem 2.000 fajta vegyi anyagot használ fel,

- a papírgyártás a világ energiafelhasználásának 4\%-áért felelős. [1]

A rendszerváltás idején fejenként $12 \mathrm{~kg}$-mal kevesebb papírt használtak a magyarok éves szinten, majd az azt követő 10 év alatt 20 tonnával nőtt az éves papírfogyasztás. [15] Jelenleg Magyarország a papírfelhasználás téren a középmezőnyben van az éves szintủ 910 ezer tonna fogyasztással (91 $\mathrm{kg}$ /fö/év). A ROADRUNNER Smarter Recycling mellett megannyi kutatás kimutatta, hogy egy dolgozó átlagosan $10.000 \mathrm{db}$ A4-es papírt használ fel egy évben, melynek $45 \%$-a (hibás nyomtatások, redundáns másolatok készítése stb.) előbb vagy utóbb a kukában végzi (egyes felmérések 60-70 \%-ra teszik ugyanezt a mutatószámot). [16,17]

A digitális technika eszközei életünk nélkülözhetetlen részévé váltak. A mindennapi tervezési, fejlesztési, üzemeltetési, felügyeleti, irányítási és értékelési feladatok internetes kezelése, a digitalizálás napjainkban és az elkövetkező időkben alaposan megváltoztatja a felsőoktatási intézmények müködését, tevékenységeinek megvalósítását is. Egy szervezet müködésének környezeti hatásainak csökkentésében jelentős szerepet játszhat a tudatos papírfelhasználás. Ugyanakkor úgy tünik, a papírt egyelöre nem helyettesíthetik az elektronika vívmányai, de azért nem árt eltünődnünk azon, vajon mindennapjaink során miképpen csökkenthetjük a papírfelhasználásunk okozta környezetterhelést. A papírorientált irodától a digitális irányba való elmozdulás pozitívumai:

- hulladék mennyiségének csökkenése,

- tisztább munkahely, rendezettebb íróasztalok,

- fenntarthatóbb munkahely, 
- rendezett és biztonságosabb adattárolás,

- autentikációval védett gyors adathozzáférés és -megosztás,

- nincs szükség nagy befogadóképességú irattárakra,

- szükségességének digitális megoldások révén,

- környezettudatos gondolkodás, környezeti fenntarthatóság elősegítése.

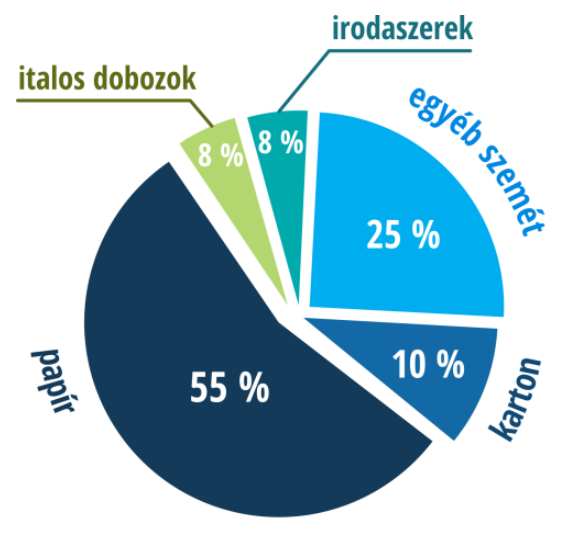

1. ábra. Irodai szemét összetétele [18]

\section{Digitális univerzum}

A digitalizáció az élet minden aspektusába beférkőző online/virtuális jelenlét, a szüntelen adat- és információcsere okos eszközök és emberek között. [19] Hacsak azt nézzük, hogy naponta 2,5 millió TB adat 'születik' és az elmúlt 2 évben keletkezett az adatok 90\%-a, akkor bátran kijelenthető, hogy a digitalizáció kérdése egyre nagyobb aktualitással bír. A globális adatmennyiség [21]:

- 1400-tól 1900-ig megkétszereződött,

- 2014-re 2 évenként megkétszereződött,

- 2017-re évenként kétszereződött,

- 2020-ra a 2013-hoz viszonyítva meg fog tízszereződni. [20]

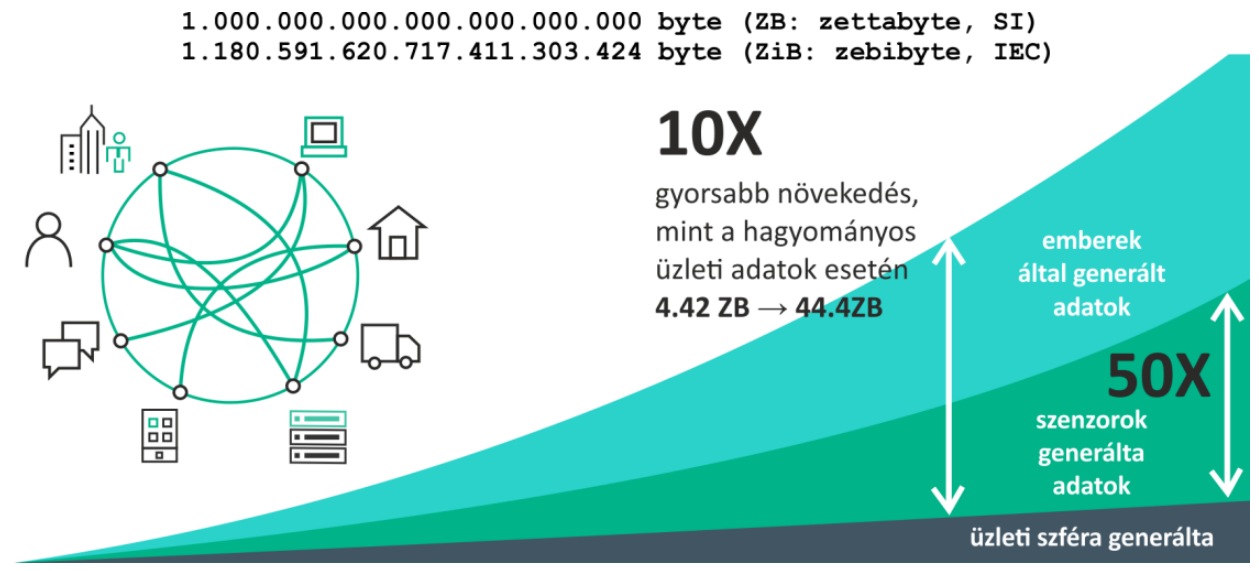

2. ábra. A globális adatmennyiség-növekedés trendje 
A globális digitalizáció kapcsán a CISCO az alábbi statisztikákat és előrejelzéseket publikálta [22]:

- 2022-re a globális népesség 60 százaléka lesz internethasználó, és több mint 28 milliárd eszköz kapcsolódik majd az internetre.

- 2022-re a vezetékes és mobileszközök, illetve kapcsolatok száma eléri a 28,5 milliárdot, amely 3,6 hálózatba kapcsolt eszközt jelent személyenként. Ez a szám 2017-ben 18 milliárd volt, 2,4 hálózatba kapcsolt eszköz személyenként,

- a Föld népességét tekintve egy főre vetítve 2014-ben percenként 1,3 MB adatforgalom generálódott, 2020-ra ez 12,4 MB/perc/före fog növekedni,

- 2022-re az adatforgalom nagyobb lesz, mint 1990-2021 között összesen egybevéve.

Solymár Károly Balázs infokommunikációért felelös helyettes államtitkár 'A digitalizáció helyzete: kihívások és célok' c. előadásában [23]. Magyarország digitális helyzetét részletekbe menően mutatja be, melyből kiderül, hogy az Európai Bizottság által a statisztikai hivatalok adatai révén elóállított DESI méri az EU tagállamok digitális társadalmának és gazdaságának helyzetét. A rangsor utolsó harmadában található Magyarország tekintetében a legerősebb területeink közé sorolhatjuk a szélessávú lefedettséget és az internethasználatot, ugyanakkor az elektronikus közigazgatás, illetve a digitális technológiák integráltsága és a humán tőke esetében viszont jelentős a lemaradásunk. A magyar GDP több mint ötödét közvetve a digitális gazdaság állítja elő, ebben élen járunk. [23,24]

A Miskolci Egyetem, mint minden egyes felsőoktatási intézmény jövőjét illetően rendkívül fontos, hogy a fő profilt, az oktatást szem előtt tartva a 21 . századi technikai megoldásokra alapozva a digitális világba beleszületett, annak aktív részeseivé vált $Z$ és alfa generációs fiatalok által preferált módszerek, kommunikációs csatornák irányába mozduljon el az oktatás.[25]

\section{Papíralapú irodai munka hátulütői}

A Software Advice 2015-ös felmérése szerint egy hagyományos papíralapú irodában a munkavállalók kevesebb, mint $30 \%$-a tölt mindösszesen csak 10 percet dokumentumok keresésével, míg $70 \%$-uk 10 perc és 6 óra közötti időtartamot. [26] A napi munkaidő 15-20\%-a tehát felesleges papírtologatással telik, melyből következően a bérek és az összes kiadás egy része kidobott pénznek tekinthető.

A digitalizáció révén racionalizálható és felgyorsítható egy sor ma még analóg módon megvalósított üzleti tevékenység, többek között a munkafolyamatok kezelése, az ajánlatokat tartalmazó levelek elkészítése. [27] Annak ellenére, hogy a globális digitalizáció világban az információ túlnyomórészt digitális módon generálódik és egyre inkább elenyészőnek mondható a papír alapú információforrás, a digitális adattartalom majdnem egyharmada papír alapúvá 'alakul át'. Ezek alapján mindenképpen foglalkozni kell a Miskolci Egyetemen is a papírfelhasználás kérdésével.

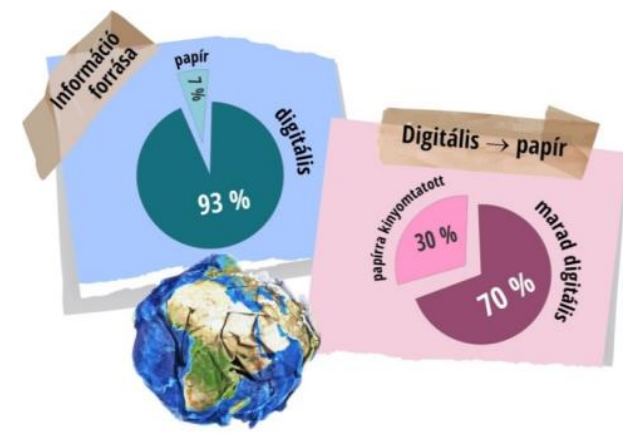

3. ábra. Papirrá transzformált digitális adatforrások aránya 


\section{Irodai papírfelhasználás a Miskolci Egyetemen}

A naprakész informatikai háttér létfontosságú az ipari igényekre történő gyors és eredményes reagáláshoz, ugyanakkor a hallgatói elégedettségén is rengeteget javítanak az innovatív eszközök és megoldások. A T-Systems által szervezett workshopokon Solymár Károly Balázs, az Innovációs és Technológiai Minisztérium infokommunikációért felelős helyettes államtitkára kiemelte: ,a digitalizáció ma már nem pusztán versenyelőny: nélküle egyre nehezebb érvényesülni egy olyan világban, amelyben az üzleti változásokra gyorsan és hatékonyan kell reagálni a talpon maradáshoz.” [29]

A globális digitalizációval összefüggésben arra kerestük a választ, hogy a Miskolci Egyetem a mindennapi ügymenet, az operatív müködés, az oktatás-kutatás során felhasznált A4-es irodai papír mennyiségével milyen ökológiai lábnyomot hagy maga után. Mivel az irodai papírfelhasználással kapcsolatos kutatásunkat 2019. utolsó negyedévében végeztük, ezért 2018-at mint a legutolsó, teljes naptári évet vettük alapul mind a papírbeszerzésre, mind az alkalmazotti létszámra vonatkozó adatokat illetően. A Miskolci Egyetem Beszerzési Osztályával és Humángazdálkodási Osztályával egyeztetve az alábbi bázisadatokból indultunk ki:

- 2018-ban 7.500 csomag $80 \mathrm{~g} / \mathrm{m}^{2}$-es A4-es másolópapír (hagyományos fehér és újrahasznosított vegyesen) került beszerzésre,

- éves beszerzést tekintve a hagyományos fehér másolópapír és az újrahasznosított papír aránya: 4:1,

- 2018. december 31-i állapot szerint az alkalmazotti létszám: 1299 fő.

A számításokhoz használt további adatok:

- 1 csomag másolópapír: 500 lap A4-es papírlapot tartalmaz,

- $1 \mathrm{db}$ A4-es papír mérete: $297 \mathrm{~mm}$ x $210 \mathrm{~mm}$,

- $1 \mathrm{db}$ A4-es papír területe: $623,7 \mathrm{~cm}^{2}$,

- $10 \mathrm{db}$ egymásra helyezett $80 \mathrm{~g} / \mathrm{m}^{2}$-es A4-es papír magassága: $1 \mathrm{~mm}$, vagyis $100 \mathrm{db}$ egymásra helyezett papírlap magassága $1 \mathrm{~cm}$.

Az előbbiek alapján a Miskolci Egyetem A4-es irodai papírfelhasználására végzett kalkulációk:

- 7.500 csomag A4-es fénymásolópapír: 7.500 x $500 \mathrm{db}=3.750 .000 \mathrm{db}$ papírlap,

- 7.500 csomag egymásra helyezett A4-es fénymásolópapír magassága: 3.750.000/10/1.000 = 375 m,

- $\quad 3.750 .000 \mathrm{db}$ egymás mellé helyezett A4-es fénymásolópapír összfelülete:

$3.750 .000 \mathrm{db} \times 623,7 \mathrm{~cm}^{2}=233.887,5 \mathrm{~m}^{2}$,

- 7.500 csomag A4-es fénymásolópapír által elfoglalt térfogat: $(3.750 .000 \mathrm{db} / 100) \times 623,7 \mathrm{~cm}^{2}=23.388 .750 \mathrm{~cm}^{3}=23,4 \mathrm{~m}^{3}$,

- 7.500 csomag A4-es fénymásolópapír tömege $\left(80 \mathrm{~g} / \mathrm{m}^{2}\right)$ :

$233.887,5 \mathrm{~m}^{2} \times 80 \mathrm{~g} / \mathrm{m}^{2}=18.711 .000 \mathrm{~g}=18,7 \mathrm{t}$,

- 1 alkalmazottra vetített A4-es papírfelhasználás:

7.500 csomag/1.299 fö = 5,77 csomag / fö, azaz

5,77 csomag/fö x 500 lap $=2.885$ lap / fö.

Ezen adatok alapján a környezetre mért hatások megvizsgálásához bevezettük az A4-es lábnyom fogalmát, mellyel egy adott mennyiségü A4-es irodai papír előállításához szükséges természeti erőforrás és energiafelhasználás, valamint a papírfelhasználási szokások alapján kalkulálható papírhulladék mennyiségét kívánjuk számszerüsíteni.

\subsection{A Miskolci Egyetem egyéves A4-es erdőlábnyoma}

A papírgyártás során 1 tonna irodai fehér papír előállításához 24 fára és 300-2600 m³ vízre (2-13 liter víz / 1 db A4-es papírlap) vízre van szükség. Papírhulladék felhasználásával 1 tonna 100 \%-ban újra- 
hasznosított papír elöállítása során 24 fa menthető meg. [31,32]

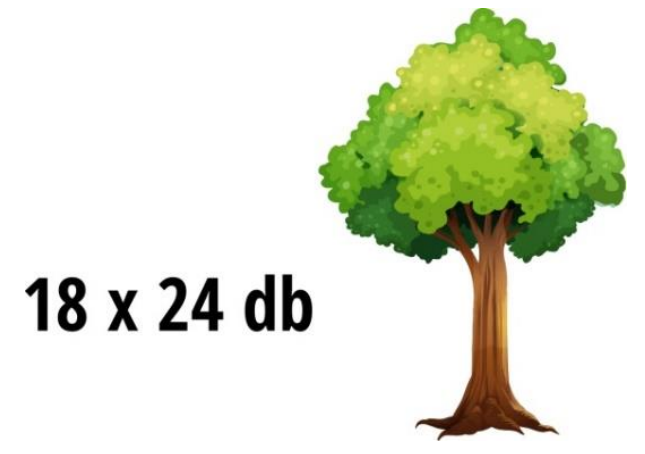

4. ábra. A Miskolci Egyetemen egy év alatt felhasznált A4-es fehér irodai papir elöállitásának erdölábnyoma

Figyelembe véve a Miskolci Egyetemen a fehér és újrahasznosított A4-es irodai papír arányát (4:1), az erdőlábnyom az alábbiak szerint módosul:

$$
18 \cdot \frac{4}{(4+1)} \cdot 24=14,4 \cdot 24
$$

Az A4-es erdőlábnyom-csökkenés tehát:

$$
(18-14,4) \cdot 24=86,4 \mathrm{db} \text { fa. }
$$

Ebböl az is következik, hogy $10 \%$-kal több újrahasznosított papír használatával (10 \%-kal csökkentve a hagyományos fehér A4-es papírfelhasználást) kicsivel több, mint 43 db fával csökkenthető a Miskolci Egyetem éves A4-es erdőlábnyoma.

\subsection{A Miskolci Egyetem egyéves A4-es vízlábnyoma}

A Miskolci Egyetemen egy év alatt felhasznált A4-es irodai papír elóállításához szükséges vízmennyiség az alábbiak szerint számítható ki. Jelölje

- $x$ az 1 tonna fehér irodai papír,

- $\quad y$ pedig az 1 tonna újrahasznosított papír elöállításához szükséges víz mennyiségét.

A Miskolci Egyetemen a fehér és újrahasznosított A4-es irodai papír aránya (forrás: Beszerzési Osztály):

$$
4: 1
$$

tehát a 18 tonnányi beszerzésből:

- 14,4 tonna hagyományos fehér A4-es papír,

- 3,6 tonna újrahasznosított A4-es papír.

A 18 tonna össztömegű papír előállitásához szükséges vízmennyiség tehát:

$$
14,4 \cdot x+3,6 \cdot y,
$$

Papírhulladék felhasználásával 1 tonna $100 \%$-ban újrahasznosított papír elöállítása során 15\%-kal csökkenthető a légszennyezés és $60 \%$-kal a vízszennyezés.[1] Ezt figyelembe véve adódik, hogy 


$$
y=(1-0,6) \cdot x
$$

amelyet (2)-be behelyettesítve:

$$
\begin{gathered}
14,4 \cdot x+3,6 \cdot 0,4 \cdot x \\
15,84 \cdot x .
\end{gathered}
$$

[31,32] alapján:

$$
x \in[300,2600] .
$$

(8)-at (5)-be behelyettesítve megkapjuk egy év alatt felhasznált A4-es irodai papír kapcsán a Miskolci Egyetem vízlábnyomát:

$$
\text { 4752...41184m }{ }^{3} \text {. }
$$

Sajnálatosan tapasztaltuk, hogy a felmérésben résztvevők visszajelzései alapján 10-ből 9 alkalmazott csak a projektek által támasztott környezeti, fenntarthatósági szempontok miatt kötelezően elöírás miatt használnak újrahasznosított papírt. Ebből kifolyólag választ akartunk kapni arra, hogy 1 csomag A4-es fehér papír újrahasznosítottal való helyettesítésével, mennyivel csökkenthető a Miskolci Egyetem A4-es vízlábnyoma.

Egy tonna újrahasznosított papírra való áttéréssel megtakarítható víz mennyisége:

(7)-be (3)-at behelyettesítve:

$$
x-y,
$$

$$
x-(1-0,6) \cdot x=0,6 \cdot x .
$$

Egy A4-es csomagra - melynek tömege: $2.500 \mathrm{~g}$ - vetítve:

$$
\begin{gathered}
\frac{2500}{1000000} 0,6 \cdot x \\
0,0015 \cdot x
\end{gathered}
$$

(6)-ot behelyettesítve adódik, hogy

$$
0,45 \ldots 3,9 m^{3} .
$$

Tehát 1 csomag A4-es újrahasznosított papírra való áttéréssel minimum 450 literrel csökkenthető a Miskolci Egyetem A4-es vízlábnyoma.

Amennyiben a Miskolci Egyetem alkalmazottjai közül 1 fó 100\%-ig áttér az újrahasznosított papír használatára, úgy a 8. fejezetben kalkulált, egy alkalmazott évenkénti 5,77 csomag A4-es papírfelhasználása kapcsán (10) alapján az alábbi vízlábnyom csökkenés érhető el:

$$
\begin{gathered}
5,77 \cdot[0,45 \ldots 3,9] \mathrm{m}^{3}, \\
2,6 \ldots 22,5 \mathrm{~m}^{3} .
\end{gathered}
$$

Tehát környezettudatos papírfelhasználással egy alkalmazott legalább 2,6 $\mathrm{m}^{3}$-rel, azaz 2.600 literrel csökkentené a Miskolci Egyetem egyéves ökológiai A4-es vízlábnyomát. 


\subsection{A Miskolci Egyetem egyéves A4-es hulladéklábnyoma}

1 tonna papírhulladék tárolásához kb. 2,3 $\mathrm{m}^{3}$ hulladéklerakó helyre van szükség. [33][34][35][36] A ROADRUNNER Smarter Recycling kutatására [16] alapozva feltételezve, hogy a felhasznált irodai papír 45 \%-a a kukában végzi, a Miskolci Egyetem egyéves irodai papírfelhasználás tekintetében az alábbi adódik:

$$
18 t \cdot 45 \% \cdot 2,3 m^{3} / t=18,63 m^{3}
$$

hulladéklerakó helyre van szükség.

\section{9. Összefoglalás}

A papír használatának azonosított okai a papír vagy a technológiai alternatívák előnyeivel, a technológia és a társadalom kapcsolatával, az egyéni viselkedés és a társadalmi gyakorlatokkal magyarázhatók. A Miskolci Egyetemen a papír felhasználásának okai, amelyeket kutatásunkban azonosítottunk, olyan folyamatoknak köszönhetők, amelyekben a papír felhasználása berögzült szokás, vagy elengedhetetlen volt (pl. törvényi vagy projekt elöírás), vagy bizonyos folyamatokba vetett bizalom hiányának oka (pl. információs rendszerekkel szembeni rossz tapasztalat, ellenszenv, elektronikus adattárolás kapcsán felmerülő biztonság megkérdőjelezése, e-aláírás el nem fogadottsága stb.).

A környezettudatosság és a fenntarthatóság nemcsak a vállalatok, cégek és a fogyasztók gondolkodásában, hanem a felsőoktatási intézmények, köztük a Miskolci Egyetem mindennapi müködése során is jelentős szerepet játszik. A Miskolci Egyetem A4-es irodai papírfelhasználása okozta ökológiai lábnyom több módon csökkenthetö:

- újrahasznosított papírhasználatra való minél nagyobb mértékủ átállással,

- az alkalmazottak környezettudatos munkavégzésre való ösztönzésével,

- komplex ügyviteli folyamatokat támogató elektronikus rendszerek bevezetésével, meglévő rendszerek továbbfejlesztésével és köztük lévő interfészek kialakításával,

- papíralapú és digitalizált munkafolyamatok közötti redundancia megszüntetésével (túlpapírozott digitális megoldások), a digitális megoldások preferálásával.

Minden egyes terület fejlesztése, javítása költségmegtakarítást, a tárolási hely csökkenését, és a fák megóvását eredményezi.

A nyomtatás alapvetően meglehetősen környezetkárosító tevékenység. Áramot, papírt és tintát is használunk hozzá, a tonerek pedig különösen veszélyes hulladékok. A Miskolci Egyetem papíralapú munkafolyamatai okozta környezeti terhelés környezetbarát betü használatával is csökkenthető. A Grey London és a Ryman együtt fejlesztette ki a Ryman Eco névre keresztelt fontot, amely áttörtségének köszönhetően jelentősen kevesebb tintával is kifogástalanul olvasható. Átlagban a standard fontokhoz képest 33\%-kal kevesebb tintát használ nyomtatáskor.[37] Ezen túlmenően, kétoldalas nyomtatással akár felére is lecsökkenhet a papírfelhasználás, mely a költségmegtakarításon túl a Miskolci Egyetem ökológiai erdö-, víz- és hulladéklábnyomát is leredukálja.

Az alkalmazottak tudatosságának növelése az irodai papírfelhasználás csökkentése terén átfogó informatikai, korszerü technikai megoldások bevezetését is szükségessé teszi. A digitális ügyviteli, dokumentumkezelő rendszerek széles körü használata áttörést hozhat az irodai papírfelhasználás terén. Online rendszerek használatával a munkavállaló és a munkáltató is eléri az adatokat, egészében látja az információkat, ezáltal felgyorsulnak a folyamatok, csökken a hibalehetőség, nem kell várni a kitöltött papírokra, nem kell azokat kinyomtatni, összegyüjteni, ellenőrizni, rögzíteni, a hibákat javítani, a hiányosságokat pótolni. 
A papírfelhasználás racionalizálása, redukálása kapcsán anyagi szempontból is találkozunk pozitív példákkal. A Bank of America például az elmúlt két évben 25\%-kal csökkentette papírfogyasztását, az elektronikus információhordozóknak (e-mail, intranet), a következetesen mindkét oldalra történő nyomtatásnak és könnyebb papírtípusok bevezetésének köszönhetően, mely révén a papírhulladék elszállításának költségeiböl is évi félmillió dollárt takarítottak meg. [38]

Fontos megjegyezni, hogy a valósághoz még közelebb álló átfogó kép adható a papírfelhasználási szokásokról és az egyes területeken a digitális irányba történő elmozdulási lehetőségekről, amennyiben egy további felmérés keretében figyelembe vesszük a napi munkafolyamat során használt valamennyi papírméretet, beazonosításra kerülnek a papírfelhasználás helyzetei (hol?, mikor?, hogyan?, miért?), továbbá összevetésre kerülnek a papír alapú munka kiváltásának alternatív megoldásai.

\section{Köszönetnyilvánítás}

A cikkben ismertetett kutató munka az EFOP-3.6.1-16-2016-00011 jelü „Fiatalodó és Megújuló Egyetem - Innovatív Tudásváros - a Miskolci Egyetem intelligens szakosodást szolgáló intézményi fejlesztése" projekt részeként - a Széchenyi 2020 keretében - az Európai Unió támogatásával, az Európai Szociális Alap társfinanszírozásával valósul meg.

\section{Irodalom}

[1] Manhertz, A., Bóbis, I.: A papír és ami mögötte van..., Zöld Újság, 2010. http://zoldujsag.hu/apapir-es-ami-mogotte-van-47148

[2] https://mek.oszk.hu/01200/01208/01208.htm Kalmár, P.: A kétezer éves papír

[3] Spencer, M., Lamont, M., Keogh, A.: (2009), Paper and the Environment, Fuji Xerox, 2014, https://www.fxs.com.au/webcontent/thepaperfacts/images/the_paper_facts_white_pa per.pdf

[4] Scobie, A.L.: Understanding printing behaviours and paper consumption at the University of Wollongong, University of Wollongong, 2015. https://ro.uow.edu.au/theses/4671

[5] Environmental impact of paper: https://en.wikipedia.org/wiki/Environmental_impact_of_paper

[6] The Two Sides Team: Our carbon footprint: How do paper products fit in? https://twosidesna.org/US/our-carbon-footprint-how-do-paper-products-fit-in

[7] United States Environmental Protection Agency: Advancing Sustainable Materials Management: 2014 Fact Sheet, Epa.gov., 16 August 2018.

[8] Environment and Climate Change Canada: 2015 Summary Report: Reviewed Facility-Reported Data, 2017. https://www.canada.ca/en/environment-climate-change.html

[9] United States Environmental Protection Agency: Toxics Release Inventory (TRI) National Analysis, 2015. http://www.epa.gov/trinationalanalysis/

[10] Environment and Climate Change Canada: National Pollutant Release Inventory (NPRI) - Pollutant Release Data Aggregated by Province, Industry Type and Substance, Five-Year Tabular Format, 2017.

[11] Hilary Feldman: Paper Cups = Unsustainable Consumption, Daily Green Tips, Environment, 2008., http://www.aboutmyplanet.com/environment/paper-unsustainable/

[12] Spitzer, N.: The impact of disposable coffee cups on the environment, 2009, https://www.sheknows.com/living/articles/810025/the-impact-of-disposable-coffee-cups-onthe-environment/

[13] Conservatree nonprofit organization: Papermaking, http://www.conservatree.org/learn/Papermaking/Papermaking.shtml

[14] Magyar Nyomdász: Tények és számok a nyomda- és papíriparról, 2015. https://www.magyarnyomdasz.hu/tenyek-es-szamok-nyomda-es-papiriparrol 
[15] https://piacesprofit.hu/klimablog/fenntarthato_fejlodes/csaknem-egy-mazsa-papirt-hasznalunkevente/

[16] https://www.roadrunnerwm.com/blog/office-worker-waste-generation

[17] https://www.bud.hu/budapest_airport/felelossegvallalas/kornyezetvedelmi_felelossegvallalas/z oldiroda/nyomtatas_masolas

[18] forrás: recycling.bins.com.au

[19] Zuti, B.: Digitalizáció_felsőoktatás_és_regionális_versenyképesség, Fiatal Kutatók XVI. Nemzetközi PEME - Konferenciája, Budapest, 2018., https://www.academia.edu/36426831

[20] Data Economy Conference, 2018., https://ivsz.hu/data-economy-conference/

[21] Coworth Technologies: The Digital Universe - how will it impact your business?, 2013. http://www.coworthtechnologies.com/blog/the-digital-universe-how-will-it-impact-yourbusiness/

[22] Cisco Visual Networking Index: Forecast and Trends, 2019. Document ID:1551296909190103, www.cisco.com

[23] Solymári, K.B.: A digitalizáció helyzete: kihívások és célok, IVSZ MENTA Konferencia, Sárvár, 2019. https://www.slideshare.net/IVSZ/a-digitalizci-helyzete-kihvsok-s-clok

[24] Korm. határozat a Digitális Kompetencia Keretrendszer fejlesztéséről és bevezetésének lépéseiről, Magyar Közlöny; 2019. évi 97. szám; 2019. június 11.; 3350. o.

[25] vezetofejlesztes.hu: 20 tipp a digitális transzformációhoz, 2019., https://vezetofejlesztes.hu/wp/wp-content/uploads/2019/20tippdigitalistranszformacio.pdf

[26] Borowski, C. (Software Advice): Become a Paperless Office With Document Management Software, IndustryView, 2015. https://www.softwareadvice.com/cms/industryview/gopaperless-with-document-management-software/

[27] https://www.hrportal.hu/hr/elkerulhetetlen-az-iroda-digitalizalasa-20150706.html

[28] Bürotika és irodakultúra: Ha eltünik a papír, megáll az élet?, 2017., https://burotika.hu/haeltunik-a-papir-megall-az-elet-2017/

[29] Pias\&Profit: A digitalizáció több, mint üzleti lehetőség, 2019. https://piacesprofit.hu/kkv_cegblog/a-digitalizacio-tobb-mint-uzleti-lehetoseg/

[30] Technokrata: Nem bízik a digitalizációban a magyar $Y$ és $Z$ generáció, 2019., http://www.technokrata.hu/lifestyle/2019/05/23/nem-bizik-a-digitalizacioban-a-magyar-y-es-zgeneracio/

[31] P.R. van Oel, Hoekstra, A.Y.: The green and blue water footprint of paper products: Methodological considerations and quantification, Value of Water Research Report Series No. 46, UNESCO-IHE Institute for Water Education, Delft, The Netherlands, 2010., https://waterfootprint.org/media/downloads/Report46-WaterFootprintPaper_1.pdf

[32] Marjainé Szerényi, Zs., Kocsis T.: Vízlábnyom: A fenntarthatóság egy új mérőszáma?, Corvinus Egyetem, 2012. http://korny.uni-corvinus.hu/publikaciok/ff-zarokotet/1/marjaineszerenyi-zsuzsanna-kocsis-tamas.pdf

[33] University of Southern Indiana: Paper Recycling Facts, https://www.usi.edu/recycle/paperrecycling-facts/

[34] Paper recycling, https://en.wikipedia.org/wiki/Paper_recycling

[35] Fredricks, S.: What can your recycled paper make?, Legal Shred, 2016., https://legalshred.com/recycling-shredded-paper-make/

[36] Dartmouth College: Forest and Paper Industry, Hanover, USA, https://www.dartmouth.edu/ cushman/courses/engs171/Paper.pdf

[37] Piac\&Profit: Miképp lehet környezetbarát egy betü? https://piacesprofit.hu/klimablog/mikepplehet-kornyezetbarat-egy-betu/ 
[38] Janicki, M.M.: Paper consumption report, 2000, https://www.cga.ct.gov/2000/rpt/2000-r-1041.htm

[39] Zöld Iroda Program: Papírfelhasználás, http://www.zoldiroda.hu/index.php/hogyan-zoldtsemirodamat-fomenu/temakorok/paprfelhasznalas 